Arch. Vet. Scienc. 3(1):57-64, 1998

Printed in Brazil

\title{
PYRUVATE KINASE ISOENZYMES FROM SUBMAXILLARY AND SUBLINGUAL SALIVARY GLANDS OF RAT (Rattus rattus norvaegicus, Berkenhout). I PURIFICATION AND PHYSICO- CHEMICAL PROPERTIES.*
}

\section{CLAUDETE D. ROSA ${ }^{1}$; DARIO OCAMPOS ${ }^{2}$; KIKUE T. SASSAKI ${ }^{3}$; MARCELO CERQUEIRA-CESAR ${ }^{4}$; RUBENS ROSA ${ }^{4}$}

${ }^{1}$ Faculdade de Odontologia de São José dos Campos, Universidade Estadual Paulista "Júlio de Mesquita Filho" São José dos Campos, São Paulo. ${ }^{2}$ Faculdade de Zootecnia e Engenharia de Alimentos, Universidade de São Paulo, Pirassununga, São Paulo. ${ }^{3}$ Faculdade de Odontologia de Araçatuba, UNESP, Araçatuba, São Paulo. ${ }^{4}$ Departamento de Medicina, Centro de Ciências Biológicas e da Saúde, Pontifícia Universidade Católica do Paraná, Curitiba, Paraná.

\begin{abstract}
Pyruvate kinase from rat (Rattus rattus norvaegicus) submaxillary and sublingual salivary glands was purified to homogeneity by a 3-step process. One step involved salting out by ammonium sulfate precipitation and two steps, column chromatography, first with phosphocellulose and elution with $0.5 \mathrm{M} \mathrm{KCl}$ and then with Blue Sepharose CL-6B eluted with 5mM PEP and $5 \mathrm{mM}$ ADP. The final specific activity of SM-PK was $324.5 \mathrm{IU} / \mathrm{mg}$ with an overall yield of $20.1 \%$. The values for SL-PK were $427.4 \mathrm{IU} / \mathrm{mg}$ and a yield of $9.5 \%$. The molecular weights of the native enzymes and their subunits, as determined by PAGE electrophoresis with or without SDS were 60.500 and 50.000 Daltons respectively, for SM-PK and 242.000 and 200.000 for SL-PK, suggesting that these enzymes were present as homotetramers. By means of cellulose acetate electrophoresis it has been demonstrated that both SM-PK and SL-PK possess only one isozymic form displaying eletrophoretic mobility similar to that of the L-type PK from rat liver and $\mathrm{M}_{2}$ type PK form rat kidney. Optimum pH for both SM-PK and SL-PK was found to be 7. 4 in Tris-HCl buffer.
\end{abstract}

Key Words: Pyruvate kinase; submaxillary glands; sublingual glands.

RESUMO - Piruvatoquinase de glândula salivar submaxilar e sublingual de rato (Rattus rattus norvaegicus, Berkenhout) foi purificada até homogeneidade por "salting out" por precipitação com sulfato de amônio seguida de cromatografia de coluna, primeiro com fosfocelulose e eluição com solução $0,5 \mathrm{M}$ de $\mathrm{KCl}$ e depois com Blue Sepharose CL-6B eluida com PEP $5 \mathrm{mM}$ e ADP 5mM. Obteve-se atividade específica final de 324,5 UI/mg com rendimento global de 20,1\% para SM-PK e de 427,4 UI com rendimento global de 9,5\% para SL-PK, com pesos moleculares de 60.500 e 50.000 Daltons determinado em eletroforese do tipo PAGE com e sem SDS, para SM-PK e de 242.000 e 200.000 para SL-PK, sugerindo, com isso que se tratam de homotetrâmeros. Por eletroforese em gel de acetato demonstrou-se que tanto SM-K como SL-K possuem somente uma forma isoenzimática com mobilidade eletroforética similar à PK tipo L de fígado de rato e do tipo $\mathrm{M}_{2}$ do rim de rato. verificou-se que o pH ótimo para ambas as enzimas é de 7,4.

Palavras-Chave: Piruvatoquinase; glândulas submaxilar; glândulas sublingual.

\section{Introduction}

Cell differentiation may imply not only changes in enzymatic expression but also modifications in metabolic pathways (NGO et al., 1983; NIJHOF et al., 1984; OSKAM et al., 1985; VORA et al., 1985). These changes achieve the most effective metabollic activity in regard to their specific function on each cell population. Several enzymes display variations in their total activity, possibly due to "de novo" synthesis (NGO et al., 1983), qualitative isoenzyme shifts

\footnotetext{
* With grants-in-aid from Fundação de Amparo à Pesquisa do Estado de São Paulo (FAPESP) and Projeto CIRMPROANTAR-CNPq n. 4503). ${ }^{(2)}$ To whom all correspondence should be sent: Claudete D. Rosa, Faculdade de Odontologia de São José dos Campos, UNESP, P.O. Box 314, 12145-000, São José dos Campos, São Paulo - Brasil.

Abbreviations used: PAGE, polyacrylamide gel electrophoresis; SDS, sodium dodecyl sulfate; PMSF, phenylmethylsulphonyl fluoride; $\beta$-ME, $\beta$ - mercaptoethanol; DTT, dithiotreitol; SM, submaxillary gland; SM-PK submaxillary gland-piruvate kinase; SL, sublingual gland; SL-PK, sublingual glandpyruvate kinase; PEP, phosphoenolpyruvate.
}

(OSKAM et al., 1985; VORA et al., 1985) and changes in kinetic and regulatory properties (HEESBEN et al., 1982). In some processes of cell differentiation, the glycolytic flux decreases with the increase in the differentiation. This fact is related to quantitative and qualitative changes in kinetic and regulatory enzymes (NGO et al., 1983; PINILLA, et al., 1982) In undifferentiated cells that need more energy, the isoenzyme forms that facilitate glycolysis are usually present (NIJHOF et al., 1984).

Pyruvate kinase (ATP: pyruvate phosphotransferase, PK, EC: 2.7.1.40) is a regulatory enzyme that catalyses the conversion of phosphoenolpyruvate (PEP) to pyruvate and the phosphorylation of ADP to ATP, in the presence of $\mathrm{Mg}^{2+}$ and $\mathrm{K}^{+}$. Pyruvate kinase exhibits a complex regulation controlled by a number of metabolites, hormones and nutitional states to produce changes in the glycolytic rates related to the energetic requirements of the cells. According to ZAMORA et al., (1992) the intracellular concentrations of substrates and effectors should regulate PK activity 
and therefore the glygolytic rates.

Four different isozymes of PK are present in mammalian tissues: $\mathrm{L}, \mathrm{M}_{1}, \mathrm{M}_{2}$ and $\mathrm{R}$ (IMAMURA and TANAKA, 1972, 1982; ENGSTROM et al., 1987). They are tetrameric molecules of similar size. The liver L-type PK displays a sigmoidal kinetics with PEP. It is highly regulated and shows hormonal and dietary controls. The muscle $\mathrm{M}_{1-\text { type is the most }}$ stable of the PK isozymes. It possesses similar kinetics, physical and chemical properties in all mammals, in contrast with the $\mathrm{M}_{2}$-type. This isozyme possesses properties that varies from specie to specie. The R-type PK from erythrocytes is similar to the Ltype in catalytic and regulatory properties but do not exhibit neither hormonal nor dietary control (IMAMURA and TANAKA, 1972, 1982; IBSEN and TRIPET, 1973; WALKER and POTTER, 1973; HALL and COTTAM, 1978; MUNDAY, et al., 1980; CARVAJAL et al., 1990).

Very few studies on carbohydrate metabolism from salivary glands were reported in the literature. Glycolysis is the most important source of energy for the rat SM glands (GOLDMAN et al., 1964; MARTIN, 1967). Pyruvate kinase of salivary glands from mouse, hamster, guinea-pig and rat shows wide kinetic variability (NICOLAU and SASSAKI, 1976). ROSA et al., (1976) showed that PK partially purified from SM, SL and parotid gland from rat is an allosteric enzyme activated by $\mathrm{FruP}_{2}$. The main aim of the present research work was the purification and the study of some kinetic properties of rat SM-PK and SL-PK, particularly in regard to the multiple isoenzyme forms present.

\section{Materials and Methods}

Sexually mature male Ratus rattus norvaegicus weighing about 200-220g were used. The rats were sacrificed by cervical dislocation and the SM and SL glands immediately removed and frozen. All purification procedures were performed at $0-4^{\circ} \mathrm{C}$. Frozen SM and SL rat glands were homogenized $(1 \mathrm{x}$ $6 \mathrm{w} / \mathrm{v}$ ) in cold $100 \mathrm{mM}$ Tris-HCl buffer, $\mathrm{pH} 7$. containing $1 \mathrm{mM} \beta$-ME, $1 \mathrm{mM}$ EDTA, $1 \mathrm{mM}$ PMSF, to inhibit proteases, and $20 \%$ glycerol $(\mathrm{v} / \mathrm{v})$ for the protection of enzyme activity. The mixture was spun down 30 minutes at $10,000 \mathrm{~g}$ in a Sorval RCB angular centrifuge. The supernatant was brought up to $70 \%$ saturation by gradual addition of solid $\left(\mathrm{NH}_{4}\right)_{2} \mathrm{SO}_{4}$, stirred for 30 minutes and spun down 20 minutes at $10,000 \mathrm{~g}$. The supernatant was discarded and the porecipitate dissolved in a minimum volume of the same extraction buffer, dialised overnight against the same buffer and finally spun down 30 minutes at 10,000 g. The dyalised enzyme solution was loaded on a phosphocellulose colums previously equilibrated with $33 \mathrm{mM}$ phosphate buffer, $\mathrm{pH} 6.5$, containing $10 \mathrm{mM} \beta-\mathrm{ME}$ and $20 \%$ glycerol $(\mathrm{v} / \mathrm{v})$.
After being washed with 3 bed volumes of the equilibrating buffer, the PK was eluted with a linear gradient of $0-0.5 \mathrm{M} \mathrm{KCl}$ and thereupon collected in $8 \mathrm{ml}$ fractions each 10 minutes. The eluated fractions were concentrated by ultrafiltration in an Amicon Cell with XM-50 membrane and the concentrated solution dyalised overnight against buffer A ( $20 \mathrm{mM}$ Tris- $\mathrm{HCl}$ containing $1 \mathrm{mM} \mathrm{MgCl} 2,0.1 \mathrm{mM}$ DTT and $20 \%$ glycerol $\mathrm{v} / \mathrm{v}$, final $\mathrm{pH}$ 9.8). The dyalised enzyme solution was loaded on a Blue-Sepharose CL-6B column previously equilibrated with buffer $\mathrm{A}(\mathrm{pH}$ 6.8). The column was extensively washed with buffer $\mathrm{A}, \mathrm{pH} 6.8$, and then with 5 bed volumes of buffer A $\mathrm{pH}$ 8.5. The column was then elluted successively by the procedure of SRIVASTAVA and BAQUER (1985), with 5 bed volumes of the following solutions: $1 \mathrm{mM}$ AMP in buffer A, $\mathrm{pH}$ 8.5; buffer A, $\mathrm{pH} 8.5$; a solution containing $1 \mathrm{mM}$ $\mathrm{NADP}^{+}$and $1 \mathrm{mM} \mathrm{NADH}+\mathrm{H}^{+}$in buffer $\mathrm{A}, \mathrm{pH} 8.5$; and, finally, buffer A, $\mathrm{pH}$ 8.5. Elution of $\mathrm{PK}$ was then performed with 5 bed volumes of a mixture of $5 \mathrm{mM}$ PEP and 5mM ADP in buffer A, pH 8.5, adjusted to a flow rate of $6 \mathrm{ml} / \mathrm{h}$. The enzyme solution was then dialysed overnight against buffer A, $\mathrm{pH} 8.5$ and stored at $-15^{\circ} \mathrm{C}$.

Polyacrilamide gel electrophoresis (PAGE) 5 $15 \%$, with or without $0.1 \%$ SDS, was carried out on the purified enzyme according to the procedure of LAEMMLI (1970) and developed according to the technique of OACKLEY et al., (1980). Molecular weight determination was performed according to WEBER and OSBORN (1969) and BRYAN (1977). Electrophoresis was carried on cellulose polyacetate strips as previously described by SUSOR and RUTTER (1971).

Activity of PK was assayed according to the technique of BÜCHER and PFLEIDERER (1955) at $30^{\circ} \mathrm{C}$ by a lactate dehydrogenase linked assay. A typical reaction mixture contained in $1 \mathrm{ml}$, in final concentrations, $50 \mathrm{mM}$ Tris- $\mathrm{HCl} \mathrm{pH}$ 7.4, 1mM ADP, $1 \mathrm{mM}$ PEP, $8 \mathrm{mM} \mathrm{MgCl} 2,70 \mathrm{mM} \mathrm{KCl}, 0.12 \mathrm{mM}$ $\mathrm{NADH}, 3 \mathrm{IU} / \mathrm{ml} \mathrm{LDH}, 0.01 \mathrm{mM}$ EDTA. The reaction rate was followed by measuring the change in absorbance at $30 \mathrm{~nm}$. One unit of enzyme was defined as the amount of enzyme that catalysed the formation of $1 \mu \mathrm{mol}$ of $\mathrm{NAD}^{+} / \mathrm{min}$.

Protein concentration was assayed by the method of BÜCHER (1947) during purification procedures, and by the method of LOWRY et al., (1951) in the remaining samples.

Enzymes, coenzymes and resins were from Sigma Chemical Co. All other chemicals were from reliable sources.

\section{Results}

Tables 1 and 2 summarize the data for the purification of SM-PK and SL-PK salted out by 
ammonium sulfate. The bulk of proteins was first eluted by $\mathrm{KCl}$ from a phosphocellulose chromatography column when SM-PK or SL-PK came along with lactic dehydrogenase (Fig 1). After ultrafiltration to concentrate PK and Blue-
Sepharose CL-6B affinity chromatography with PEP and ADP elution (Fig. 2), SM-PK and SL-PK displayed specific activities of 324 and $427 \mathrm{IU} / \mathrm{mg}$ protein and an overall yield of 20.1 and $9.5 \%$ respectively.

Table 1. Steps of pyruvate kinase purification from rat submandibular salivary gland.

\begin{tabular}{|c|c|c|c|c|c|c|c|c|}
\hline \multirow[t]{2}{*}{ Stepes } & \multirow[t]{2}{*}{ Volume } & \multicolumn{2}{|c|}{ Proteins } & \multirow{2}{*}{$\begin{array}{c}\mathrm{AE} \\
(\mathrm{U} / \mathbf{m l})\end{array}$} & \multirow{2}{*}{$\begin{array}{l}\text { AEE } \\
\text { (V/mg } \\
\text { prot.) }\end{array}$} & \multirow{2}{*}{$\begin{array}{c}\text { AEE } \\
\text { (total) }\end{array}$} & \multirow{2}{*}{$\begin{array}{l}\text { Yierd } \\
(\%)\end{array}$} & \multirow{2}{*}{$\begin{array}{c}\text { Purification } \\
\text { (x) }\end{array}$} \\
\hline & & $\begin{array}{c}\text { per/ml } \\
\text { (mg) }\end{array}$ & total & & & & & \\
\hline Homogeneiza-tion & 65,0 & 19,62 & 1275,3 & 20,0 & 1,019 & 1800 & 100 & 1,0 \\
\hline $\begin{array}{l}\text { Precipitation with } \\
70 \%\left(\mathrm{NH}_{4}\right)_{2} \mathrm{SO}_{4} \text { and } \\
\text { dyalysis }\end{array}$ & 21,0 & 17,66 & 870,16 & 42,0 & 2,878 & 882,0 & 67,9 & 2,3 \\
\hline $\begin{array}{l}\text { Phosphocellulase } \\
\text { chromatography and } \\
\text { dyalysis }\end{array}$ & 3,5 & 1,48 & 5,18 & 180,2 & 121,76 & 630,7 & 48,5 & 119,5 \\
\hline $\begin{array}{l}\text { Chormatography in Blue } \\
\text { Sepharose CL-6B }\end{array}$ & 2,0 & 0,067 & 0,134 & 130,9 & 1953,7 & 261,8 & 20,1 & 1917,3 \\
\hline
\end{tabular}

Table 2. Steps of pyruvate kinase purification from rat sublingual salivary glands.

\begin{tabular}{|c|c|c|c|c|c|c|c|c|}
\hline \multirow[t]{2}{*}{ Stepes } & \multirow[t]{2}{*}{ Volume } & \multicolumn{2}{|c|}{ Proteins } & \multirow{2}{*}{$\begin{array}{c}\mathbf{A E} \\
(\mathbf{U} / \mathbf{m l})\end{array}$} & \multirow{2}{*}{$\begin{array}{c}\text { AEE } \\
\text { (V/mg } \\
\text { prot.) }\end{array}$} & \multirow{2}{*}{$\begin{array}{c}\text { AEE } \\
\text { (total) }\end{array}$} & \multirow{2}{*}{$\begin{array}{c}\text { Yierd } \\
(\%)\end{array}$} & \multirow{2}{*}{$\begin{array}{c}\text { Purification } \\
\text { (x) }\end{array}$} \\
\hline & & $\begin{array}{c}\text { per/ml } \\
(\mathrm{mg})\end{array}$ & total & & & & & \\
\hline Homogeneiza-tion & 18 & 9,81 & 176,58 & 113 & 11,52 & 2034,0 & 100 & 1 \\
\hline $\begin{array}{l}\text { Precipitation with } \\
70 \%\left(\mathrm{NH}_{4}\right)_{2} \mathrm{SO}_{4} \text { and } \\
\text { dyalysis }\end{array}$ & 9 & 2,80 & 25,2 & 92 & 32,86 & 828,07 & 40,7 & 2,85 \\
\hline $\begin{array}{l}\text { Phosphocellulase } \\
\text { chromatography and } \\
\text { dyalysis }\end{array}$ & 4,5 & 0,15 & 0,675 & 151,0 & 1006,67 & 679,36 & 33,4 & 87,4 \\
\hline $\begin{array}{l}\text { Chormatography in } \\
\text { Blue Sepharose CL-6B }\end{array}$ & 1,5 & 0,05 & 0,075 & 128,7 & 2574,00 & 193,05 & 9,5 & 223,1 \\
\hline
\end{tabular}

Fig 1. Phosphocellulose chromatography of pyruvate kinase from rat submaxillary and sublingual glands. Phosphocellulose was packed in a 2,5 x 29,5 cm column and equilibrated with 3 bed volumes of $33 \mathrm{mM}$ phosphate buffer, $\mathrm{pH} 6,5$, containing $10 \mathrm{mM} \beta \mathrm{ME}$ and $20 \%$ glycerol (v/v). The flow rate was maintanied at $3 \mathrm{ml} / 10 \mathrm{~min}$. After loading the column with the $70 \%\left(\mathrm{NH}_{4}\right)_{2} \mathrm{SO}_{4} \mathrm{precipitate}$ containing $25,07 \mathrm{IU} / \mathrm{ml}$, a linear gradient of $0-500 \mathrm{mM} \mathrm{KC1}$ in the same buffer was used to eluate the bulk protein and the PK. Most of the LDH activity, also present in the preparation, was eluted along the peak of the bulk protein. 
Fig. 2. Blue Sepharose CL-6B chromatography of pyruvate kinase from rat submaxillary and sublingual glands. The fractions containing SM-PK and SL-PK obtained in the experiment in Fig. 1, were concentrated by ultrafiltration through Millipore membranes and loaded into a Blue Sepharose CL-6B column $(1,6 \times 0,9 \mathrm{~cm})$ previously equilibrated with buffer A $(20 \mathrm{mM}$ $\mathrm{Mg} \mathrm{Cl}_{2}, 0,1 \mathrm{mM}$ DTT and $20 \%$ glycerol) at $\mathrm{pH} 6,8$. The column was then alternatively washed with a mixture of $1 \mathrm{mM}$ $\mathrm{NADP}^{+}$and or $1 \mathrm{mM} \mathrm{NADH}$. Buffer $\mathrm{A}$ at $\mathrm{pH} 8,5$ with a mixture of $5 \mathrm{mM}$ PEP and $5 \mathrm{mM} \mathrm{ADP}$, at $8 \mathrm{ml} / \mathrm{h}$ as flow rate, was used to eluate PK.

Fig. 3. PAGE electrophoresis containing 5 to $15 \%$ polycrilamide gel with $0.1 \%$ SDS. Samples of different steps of PK purification from submaxillary (SM) and sublingual (SL) salivary glands as well as standard proteins were used as follows: Standard: $30 \mu \mathrm{g}$ of a mixture of proteins containing phosphorylase $\mathrm{b}$, albumin, eggalbumin, carbonic anhydrase, and trypsin (MW: 94,000; 67,000; 43,000; 30,000; and 20,100 respectively); $100 \mu \mathrm{g}$ of the SM and SL crude extracts (SM EB and SL $\mathrm{EB}) ; 50 \mu \mathrm{g}$ of each eluate from the phosphocellulose (PC) and Blue Sepharose (BS) columns. 
Pyruvate Kinase from Rat Salivary Glands

Fig. 4. Molecular weight of pyruvate kinase from SM and SL rat glands in SDS-PAGE. The experiment was carried out in a gel gradient of $5-15 \%$ polycrylamide containing $0,1 \%$ SDS. Reference proteins $(30 \mu \mathrm{g})$ contained: Phosphorylase b (mol. wt. 94,000), Albumin (mol wt 67,000); Olvabumin (mol wt 43,000), Carbonic anhydrase (mol. wt. 30,000), Trypsin (mol. wt. 20,100); SM-PK (mol wt. 60,500); SL (mol. wt. 50,000).

Fig. 5. Ferguson's plot of the migration of SM and SL rat glands PK and standard proteins, (A) shows log Rf against percent of acrilamide. (B) Graphic projection of the log mw of the delaying coefficient $\mathrm{K}_{\mathrm{R}}$ of the same proteins. Proteins were bovine serum albumin (BSA): I (monomer, mol wt 66,00); II (dimer, mol. wt 132,000); III (trimer, mol. wt 198.000); MC-PK: rabbit muscle PK; rat glands SM-PK and SL-PK. 
The purified enzymes were found to be homogeneous by PAGE electrophoresis either in the presence or in the absence of SDS which produces only a single band (Fig. 3). The apparent MW of the native SM-PK and SL-PK (Fig. 4) were estimated to be 242,000 and 200,000 respectively by PAGE electrophoresis in non-denaturing conditions. The MW were calculated by the Fergunson's plot (Fig. $5 \mathrm{~A}$ ) according to BRYAN (1977). Molecular weights of the SM-PK and SLPK subunits were found to be respectively 65,500 and 50,000 daltons by SDS-PAGE (Fig. 5 B), showing that these enzymes are homotetramers in nature.

The effect of $\mathrm{pH}$ on enzyme activity was assayed with $50 \mathrm{mM}$ imidazole- $\mathrm{HCl}$, with $50 \mathrm{mM}$ Tris- $\mathrm{HCl}$ and with $100 \mathrm{mM}$ glycine- $\mathrm{NaOH}$ buffers. For both SM-PK and SL-PK purified enzymes, maximum activity was reached at $\mathrm{pH} 7.4$ in Tris$\mathrm{HCl}$ buffer.

Isoenzyme forms (Fig. 6) were studied by electrophoretic mobility in acetate cellulose strips according to the technique of SUSOR and RUTTER (1971). For comparative purposes, isoenzyme patterns of rat liver, kidney and skeletal muscle are also shown. Electrophoretic mobility of SM-PK was found to be similar to that one of rat liver L-type. On the other hand, electrophoretic mobility of SL-PK was found to be similar to that of rat kidney $\mathrm{M}_{2}$-type.

Fig. 6. Electrophoretic profiles of rat tissues multiple forms of pyruvate kinase compared with SM and SL-PK rat glands. Electrophoresis was carried out, for $3 \mathrm{~h}$, on strips of cellulose acetate, at $250 \mathrm{~V}$ in $10 \mathrm{M} \backslash \mathrm{mM}$ imidazole- $\mathrm{HCl} \mathrm{pH} 7,4$ buffer containing $500 \mathrm{mM}$ sucrose, $1 \mathrm{mM}$ Fru $\mathrm{P}_{2}$ and $10 \mathrm{mM} \beta \mathrm{ME}$. The bands were developed in ionagar $(5 \mathrm{mg} / \mathrm{ml}) \mathrm{plates}$ containing $50 \mathrm{mM}$ imidazole- $\mathrm{HCl} \mathrm{pH}$ 7,5 buffer, $8 \mathrm{mM} \mathrm{MgCl}$, $70 \mathrm{mM} \mathrm{KCl,} \mathrm{0,01} \mathrm{mM} \mathrm{EDTA,} 2 \mathrm{mM}$ PEP, $1 \mathrm{mM} \mathrm{ADP}, 0,12$ mM NADH, $1 \mathrm{mM}$ Fru- $\mathrm{P}_{2}, 3 \mathrm{IU} / \mathrm{ml} \mathrm{LDH}$. After $30 \mathrm{~min}$., the plate was placed under a Kodabromide F-5 photographic paper and exposed thereafter 3 min under UV light.

\section{Discussion}

Purification procedures for PK from animal tissues generally includes a combination of salting out by ammonium sulfate precipitation and DEAESephadex, CM-Sephadex or phosphocellulose ionic exchange chromatography and BS-4B or CL-6B affinity chromatography (ZAMORA et al., 1992; SRIVASTAVA and BAQUER, 1985; HARKINS et al., 1977; SHERING et al., 1982; KAPOOR and VENKITASUBRAMANIAN, 1983; MICHAELIDES, et al., 1985; CHRISPELLES and GADE, 1985; OCAMPOS, et al., 1986;
CALOMENOPOULOU et al., 1989; ROSA et al., 1994). In the present research we established a sequential step for the purification of SM-PK and SL-PK, using precipitation by salting out with ammonium sulfate at $70 \%$ saturation, chromatography in a phosphocellulose column followed by elution by a 0 to $500 \mathrm{mM}$ potassium chloride linear gradient at a constant $\mathrm{pH}$ and, finally, by affinity chromatography in BlueSepharose CL-6B followed by elution with $5 \mathrm{mM}$ ADP and $5 \mathrm{mM}$ PEP. This procedure allowed a 1917 and 223-fold purification for SM-PK and SL$\mathrm{PK}$ respectively and as a consequence, to obtain a 
highly pure enzyme preparation near to homogeneity as judged by PAGE with and without SDS. The preparations were fairly stable at $-15^{\circ} \mathrm{C}$ for at least 2 months in $20 \mathrm{mM}$ Tris- $\mathrm{HCl} \mathrm{pH} 6.8$ buffer containing $1 \mathrm{mM} \mathrm{MgCl}, 0.1 \mathrm{mM}$ DTT and $20 \%$ glycerol $(\mathrm{v} / \mathrm{v})$.

In mammalian tissues, PK possesses at least four isoenzymes - $\mathrm{M}_{1}, \mathrm{M}_{2}, \mathrm{~L}$ and $\mathrm{R}$ - which can be distinguished by their chemical, kinetics, eletrophoretic and immunologic parameters. The $\mathrm{M}_{1}$-type is the only one PK in muscle. Besides, it is the predominant form in brain, while R-type is present in red blood cells. The L-type is the major form of $\mathrm{PK}$ in liver. $\mathrm{M}_{2}$-type of $\mathrm{PK}$ is widely distributed in glycolytic tissues as thymus, spleen, lung, adipose tissue, kidney, testis, ovary, fetal tissues. The concentration of the $\mathrm{M}_{2}$-type of PK increases with the growth of cancer cells, in contrast with the L-type that experiences a decrease in concentration in tumor cells. Systematic studies (37) on differentiating and dedifferentiating rat tissues show the predominance of $\mathrm{M}_{2}$-type of $\mathrm{PK}$ in fetal tissues, shifting to the isoenzyme patterns of adult tissues which possess specialized physiological functions.

IMAMURA and TANAKA (1982) established the electrophoretic pattern of PK from normal adult rat tissues by using polyacrylamide gel electrophoresis. Type $\mathrm{L}$ moves faster toward the anode, while the $\mathrm{M}_{2}$-type moves slower, the $\mathrm{M}_{1}$ type displaying an intermediate mobility. The $\mathrm{R}$ isoenzyme is kinetically similar to the L-type but can be distinguished electrophoretically from the $\mathrm{M}_{1}, \mathrm{M}_{2}$ and L-types by separating from them and moving towards the anode rather slower than the Ltype (IMAMURA et al., 1972). According to the results shown here, eletrophoretic mobility of SMPK and SL-PK from rat salivary glands was similar to that ones of $\mathrm{L}$ and $\mathrm{M}_{2}$-types respectively from rat liver and kidney. The specific activity of SMPK (324 IU/mg protein) was found to be comparable to the specific activity of the L-type, while the value for SL-PK specific activity (427 $\mathrm{IU} / \mathrm{mg}$ protein) was found to be similar to the $\mathrm{M}_{2}$ type (HALL and COTTAM, 1978)

The reported molecular weights for the L-type isozymes ranged from 193,000 to 265,000 and for the $\mathrm{M}_{2}$-isozymes from 190,000 to 250,000 . The isozymes possess a tetrameric structure, the four monomers being of equal molecular weight and similar structure. They cannot be separated by poliacrylamide gel electrophoresis in the presence of sodium dodecyl sulfate (HALL and COTTAM, 1978; IMAMURA et al., 1972; CORCORAN et al., 1976; HARKINS et al., 1977). The apparent molecular weights of SM-PK and SL-PK from rat salivary glands are about 242,000 and 200,000 ( \pm $2 \%$ ), as determined by the PAGE technique in non- dissociating conditions. These values are in the range of those reported for rat tissues $\mathrm{L}$ and $\mathrm{M}_{2}$ types of PK: from 193,000 to 265,.000 for the Ltype isozymes and from 190,000 to 250,000 for the $\mathrm{M}_{2}$ (IMAMURA et al., 1973; CORCORAN et al., 1976; HARKINS et al., 1977; COTTAM et al., 1969).

The optimum $\mathrm{pH}$ for both SM-PK and SL-PK was found to be near 7.4. This effect was tested over different $\mathrm{pH}$ ranges: 6.4-7.2 with $50 \mathrm{mM}$ imidazole- $\mathrm{HCl}$ buffer; 7.4-8.4 with $50 \mathrm{mM}$ Tris$\mathrm{HCl}$ buffer; and 9.0 with $100 \mathrm{mM}$ glycyl-NaOH buffer. After attaining maximum activity at $\mathrm{pH} 7.4$ SL-PK displays a residual activity in the alkaline band near $\mathrm{pH}$ 9.0. The optimum $\mathrm{pH}$ of 7.4 for SM$\mathrm{PK}$ is considerably higher than that one observed for L-type isozyme isolated from many different mammals (HALL and COTTOM, 1978).

\section{REFERENCES}

BRYAN, J.K. Molecular weights of protein multimers from polyacrylamide gel electrophoresis. Analyt. Biochem. 78:513-519, 1977.

BÜCHER, T. Uber ein phosphatubertragens des gärung-ferment. Biochem. Biophys. Acta. 1:292, 1947.

BÜCHER, T.; PFLEIDERER, G. Pyruvate kinase from muscle. In Methods in Enzymology (Edit. Colowick S.P. and Kaplan N.O.), Academic Press, New York. 1:435-440, 1955.

CALOMENOPOULOU, M.; KALOYIANNI, M.; BEIS, I.D. Purification and regulatory properties of pigeon erythrocyte pyruvate kinase. Comp. Biochem. Physiol. 93B(3):697-706, 1989.

CARVAJAL, N.; GONZALES, R.; KESSI, E. Aspartate activation of pyruvate kinase from the kidney of Concholepas concholepas (Gastropoda: Muricidae). Comp. Biochem. Physiol. 95B(1):85-89, 1990.

CHRISPEELLS, J.; GADE, G. Purification and characterization of pyruvate kinase from the foot muscle of the cockle Cardium tuberculatum. Comp. Biochem. Physiol. 82B(1):163-172, 1985.

CORCORAN, E.; PHELAN, J.J.; FOTTRELL, P.F. Purification and properties of pyruvate kinase from human lung. Biochem. Biophys. Acta, 446:96-104, 1976.

COTTAM. G.L.; HOLLENBERG, P.F.; COON, M.J. Subunit structure of rabbit muscle pyruvate kinase. $J$. Biol. Chem. 244:1481-1486, 1969.

ENGSTROM, L.; ECKMAN, P.; HUMBLE, E.; ZEITTERQUIST, O. Pyruvate kinase. In The Enzymes, $3^{\text {rd }}$ Edition: Control by Phosphorylation, Part B. Specific Enzymes. 13:44-75, New York, Academic Press, 1987.

GOLDMAN, J.; ROSALES, F.; VILLAVICENZIO, M.; GUERRA, R. Pathways of glucose metabolism in rat submaxillary gland. Biochem. Biophys. Acta. 82:303312, 1964.

HALL, E.R.; COTTAM, G.L. Isozymes of pyruvate kinase in vertebrates: their physical, chemical, kinetic and immunological properties. Int. J. Biochem. 9:785-793, 1978. 
HARKINS, R.N.; BLACK, J.A.; RITTENBERG, M.B. $\mathrm{M}_{2}$ isozyme of PK from human kidney as the product of a separate gene: Its purification and characterization. Biochemistry, 16, 3831-3837, 1977.

HARKINS, R.N.; BLACK, J.A.; RITTENBERG, M.B. Purification and characterization of human muscle pyruvate kinase. Can. J. Biochem. 55:301-307, 1977.

HEESBEEN, E.C.; RIJKSEN, G.; BATENBURG, J.J.; van GOLDE, M.G.L.; STAAL. G.E.J. Phosphofructokinase in rat lung during perinatal development: characterization of subunit composition and regulation by fructose-2,6-bisphosphate and glucose-1,6-bisphosphate. Biochem. Biophys. Acta. 924:284-91, 1987.

IBSEN, K.H.; TRIPPET, P.A. Comparation of kinetic parameters obtained with three major noninterconvertible enzymes of rat pyruvate kinase. Archs.Biochem. Biophys. 156:730-744, 1973.

IMAMURA, K.; TANAKA, T. Multimolecular forms of pyruvate kinase from rat and other mammalian tissues. I. Eletrophoretic studies. J. Biochem. 71:1043-1051, 1972.

IMAMURA, K.; TANIUCHI, K.; TANAKA, T. Multimolecular forms of pyruvate kinase. II. Purification of $\mathrm{M}_{2}$-Type pyruvate kinase from Yoshida Ascites Hepatoma 130 cells and comparative studies on the enzymological and immunological properties of the three types of $\mathrm{PK} \mathrm{L}, \mathrm{M}_{1}$ and $\mathrm{M}_{2} . J$. Biochem. 72:1001-1015, 1972.

IMAMURA, K.; TANAKA, T.; NISHINA, T.; NAKASHIMA, K.; MIWA, S. Studies on pyruvate kinase deficiency. II. Electrophoretic, kinetic, and immunological studies on pyruvate kinase of erythrocytes and other tissues. J. Biochem. 74:1165-1175, 1973.

IMAMURA, K.; TANAKA, T. Pyruvate kinase isozymes from rat. In Methods of Enzymology, Part E: Carbohydrate Metabolism (Ed.: W.A. Wood) Vol. 90, pp. 150-165, New York, Academic Press, 1982.

KAPOOR, R.; VENKITASUBRAMANIAN, T.A. Purification and properties of pyruvate kinase from Mycobacterium smegmatis. Archs. Biochem. Biophys. 225(1):320-330, 1983.

LAEMMLI, U.K. Cleavage of structural proteins during the assembly of the head of the bacteriophage T4. Nature. 227:680-685, 1970.

LOWRY, D.R.; ROSEBROUGH, N.J.; FARR, A.L.; RANDALL, R.J. Protein measurement with the Folin phenol reagent. J. Biol. Chem. 193:265-275, 1951.

MARTIN, K. Metabolism of salivary glands. In: Handbook of Physiology, Washington, American Physiological Society. 2(6):581-593, 1967.

MICHAELIDIS, B.; LAZOU, A.; BEIS, I. Purification, catalytic and regulatory properties of pyruvate kinase from the foot of Patella caerulea (L). Comp. Biochem. Physiol. 82B(2):405-412, 1985.

MUNDAY, K.A.; GILLES, I.G.; POAT, P.C. Review of the comparative biochemistry of pyruvate kinase. Comp. Biochem. Physiol. 67B:403-411, 1980.

NGO, J.L.; CHUTE, H.; SANDERS, D.A.; ORLANDO, R.A.C.; IBSEN, K.H. Regulation of pyruvate kinase expression and growth in mastocytoma cells. Exp. Cell Res. 149: 565-575, 1983.
NICOLAU, J.; SASSAKI, K.T. Metabolism of carbohydrate in the major salivary glands of rat. Archs. Oral. Biol. 21(11):659-661, 1976.

NIJHOF, W.; WIERENGA, P.K.; STAAL, G.E.J.; JANSEN, G. Changes in activities and isoenzyme patterns of glycolytic enzymes during erythroid differentiation in vitro. Blood, 64:607-613, 1984.

OACKLEY, B.R.; KIRSCH, D.R.; MORRIS, N.R. A simplified ultrasensitive silver stain for detecting proteins in polyacrylamide gel. Analyt. Biochem. 105:631-663, 1980.

OCAMPOS, D.; ROSA, C.D.; RODRIGUES, E.; ROSA, R. Purification of muscle pyruvate kinase and lactic dehydrogenase and stability of pyruvate kinase from fish Mugil lisa and Chaetodicterus faber. Arq. Biol. Tecnol. 29(4):699-705, 1986.

OSKAM, R.; RIJKSEN, G.; STAAL, G.E.J.; VORA, S. Isozymic composition and regulatory properties of phosphofructokinase from well-differentiated and anaplastic medullary thyroid carcinomas of rat. Cancer Res. 45:135-142, 1985.

PINILLA, M.; PEREZ-ARTES, E.; RONCALES, P.; TEJERO, C.; LUQUE, J. Estudio de las enzimas reguladoras glicoliticas en eritrocitos, reticuloticos y celulas in-maduras de medula osea de rata. Rev. Esp. Fisiol. 38, Suppl.: 97-100, 1982.

ROSA, R.; GRIECO, M.L.; NICOLAU, J. Purificação parcial da PK de glândulas salivares de rato. Ciência e Cultura. 9:458, 1976.

ROSA, R.; ZAMORA, J.M.; ROSA, C.D.; RODRIGUES, E.; BACILA, M. Kinetic properties of pyruvate kinase purified from the flesh muscle of the Antarctic krill Euphausia superba. DANA. Proc. NIPR. Symp. Polar Biol. 7:103-109, 1994.

SCHERING, B.; EIGENBRODT, E.; LINDER, D.; SCHONER, W. Purification and properties of pyruvate kinase Type-M2 from rat lung. Bioch. Biophys. Acta. 717:337-347, 1982.

SRIVASTAVA, L.K.; BAQUER, N.Z. Purification and properties of rat brain pyruvate kinase. Archs. Biochem. Biophys. 236(2):703-713, 1985.

SUSOR, W.A.; RUTTER, W.J. Method of detection of pyruvate kinase, aldolase and other piridine nucleotide linked enzyme activities after electrophoresis. Analyt. Biochem. 43:147-155, 1971.

VORA, S.; HARPER, J.P.; KNOWLES, D.M. Alterations in the activity and isozymic profile of human phosphofructokinase during malignant transformation in vitro and in vivo. Transformation and progression linked discriminants of malignancy. Cancer Res. 45:2953-3001, 1985.

ZAMORA, J.M.; ROSA, C.D.; BIANCONCINI, M.S.C.; BACILA, M. Purification and properties of pyruvate kinase from the striated muscle of the ice-fish Chaenocephalus aceratus Löenberg. Int. J. Biochem. 24(11):1833-1840, 1992.

WALKER, P.R.; POTTER, V.R. Allosteric properties of a pyruvate kinase isoenzyme from rat liver cells in culture. J. Biol. Chem. 248(13):4610-4616, 1973.

WEBER, K.; OSBORN, M. The reliability of molecular weight determination by dodecyl sulphate-polyacrylamide gel electrophoresis. J. Biol. Chem. 244:4406-4412, 1969. 